iron-bacteria have been known to occur, and the importance of taking drinking water direct from the main, and of keeping household cisterns covered. The Museum is indebted to the staff of the Water Examination Department of the Metropolitan Water Board for help in the preparation of this exhibit.

\section{The Aquarium of the New York Zoological Society}

The fortieth annual report of the New York Zoological Society (June 1936) contains a report on the aquarium, written by the assistant director, $\mathrm{Mr}$. Charles M. Breder, jun. There has been much activity both in improving equipment and collecting fishes and invertebrates for the aquarium. Besides this, many fishes have been hatched, including whitefish, Chinook salmon, rainbow trout and muskallunge, and the young handed over to the Now York City Water Department for distribution in public waters. Studies on the nature of electrical energy discharged by such fishes as the electric eel were continued by Mr. Coates. After many experiments, it was found that the electricity discharged by an eel could be made to light a neon tube, and this led to a daily demonstration for the benefit of the public. Mr. Breder himself is studying details of reproductive habits of fishes, including five species of sunfish, the stickleback, Apeltes quadracus, and the catfish, Villarius catus, and has published several papers on this subject. Besides work by the staff, a number of visitors have made use of the aquarium facilities during the year.

\section{The Parliamentary Science Committee}

THE annual general meeting of the Parliamentary Science Committee was held at the House of Commons on November 26, the Earl of Dudley presiding. The officers elected for the ensuing year were: President, The Earl of Dudley; Chairman, Sir Arnold Wilson; Vice-Chairman, Prof. B. W. Holman; and Hon. Secretary and Treasurer, Mr. H. W. J. Stone. According to the annual report, four more institutions were affiliated to the Committee during 1936, and others have the subject under consideration. The total aggregate membership of the affiliated institutions now exceeds 100,000 . During the last session, the Committee was active in approaching Government departments, and in promoting questions in Parliament on a variety of topics. The outstanding feature of the year's work has been the consideration of a memorandum how best to finance and develop scientific and industrial research. The investigations into this subject have not yet been completed. During the past year the following members of parliament have joined the Committee: Lord Melchett, Prof. J. Graham Kerr, Mr. Andrew MacLaren and Sir Philip Dawson.

\section{Bright Fireball of November 14}

AT about 8.45 p.m. on November 14, a very bright fireball was seen by a number of people in different parts of Ireland. All the accounts agree in describing it as extremely brilliant, showing lights of various colours-white, blue, and red-and moving fairly slowly earthwards. Some of those who saw it allege that it lighted up the country, a road being visible for half a mile ahead, or the earth being as bright as day. Many people were terrified by the apparition, and one girl collapsed with fright. Most of the accounts come from Dublin and Wicklow, but it was also seen in Co. Tipperary, and a correspondent there describes it in terms almost similar to those used by others in eastern Ireland, namely, "it seemed very close at hand and lighted the whole place up". A report from Co. Armagh, Northern Ireland, asserts that three minutes after its disappearance a dull rumbling noise like distant thunder was heard. No one has given its position at beginning or ending with reference to the stars; indeed it does not appear that any stars were visible, at least for the observers in eastern Ireland. For this reason it is quite impossible to compute its path. Judging by the vague descriptions of its direction, it was probably falling nearly vertically somewhere about the middle of Ireland, probably a little towards the west.

\section{Three Large Sunspots}

A consprcuous feature of present solar activity is the appearance on the disk at the same time of three large sunspots, each being visible to the naked eye. Foggy weather in London and elsewhere on November 28 provided almost ideal conditions for direct observation without a telescope, and a number of people, who were previously quite unaware of the existence of the spots, discovered them independently for themselves. From a photograph obtained at the Royal Observatory, Greenwich, on November 27, the following data are derived :

$\begin{array}{cccc}\text { Date on Disk } & \begin{array}{c}\text { Central Meridian } \\ \text { Passage }\end{array} & \text { Latitude } & \text { Area } \\ & \text { Nov. 29.3 } & 17^{\circ} \mathrm{N} . & 1400 \\ \text { Nov. 23-Dec. 5 } & \text { Nov. } 29 \cdot 4 & 11^{\circ} \mathrm{S} . & 1000 \\ \text { Nov. 23-Dec. 5 } & \text { Dec. 2.2 } & 14^{\circ} \text { S. } & 1400 \\ \text { Nov. 25-Dec. 8 } & \text { Dec }\end{array}$

Areas are corrected for foreshortening and are given in millionths of the sun's visible hemisphere.

Under favourable conditions, a single spot of area 500 millionths may be detected without a telescope. Including the three present spots, nineteen naked-eye spots have already been recorded this year. Since the frequency curve of these large spots approximates closely to the more representative curve given by all spots or by their mean daily area, an even greater number of large spots may be expected in 1937-38, the epoch of the anticipated maximum of the present 11-year cycle.

\section{The Night Sky in December}

ON December $22^{\mathrm{d}} 0^{\mathrm{h}}$ the sun enters, at the winter solstice, the sign Capricornus; in the latitude of London the nights are then $16 \frac{1}{4}$ hours in duration. The moon is new on December 13 at $23 \frac{1}{2} \mathrm{~h}$ and full on December $28^{\mathrm{d}} 4^{\mathrm{h}}$ U.T. At new moon an annular eclipse of the sun is visible in the antipodes (local time December 14)-the central line, along which the duration of annularity is $5 \frac{1}{2}-7 \frac{1}{2} \mathrm{~min}$., crossing 
Australia and the North Island of New Zealand. Among the seven lunar occultations visible at Greenwich, the disappearance of $A$ Tauri (mag. 4.5) may be noted on December 25 at $20^{\mathrm{h}} 0.9^{\mathrm{m}}$ at $120^{\circ}$ from the north point of the moon's disk. Of the planets visible, Venus is a conspicuous object (mag. $-3 \cdot 6$ to $-3 \cdot 7$ ) setting about $19^{\mathrm{h}} 0^{\mathrm{m}}$ in mid-December. On December $17^{\mathrm{d}} 17^{\mathrm{h}}$ the planet is in conjunction with the moon, below which it will be situated $6^{\circ}$. Mercury is not very accessible to observation, but may be seen during the last week of the year near the southwest horizon at $17^{\mathrm{h}}$. Mars rising after midnight is in Virgo; on December 21 it passes $3^{\circ}$ north of the bright star, Spica. Saturn, in Aquarius, sets about $23^{\mathrm{h}}$ in mid-December ; on Dec. $20^{\mathrm{d}} 19^{\mathrm{h}}$ the planet is in conjunction with the moon, and on December 28 the sun will be in the plane of the rings, the minor axis of which is now about $2^{\prime \prime}$. In addition to the planets, the skies offer at any time during a fine night in December an attractive field for observation. At $22^{\mathrm{h}}$ in the middle of the month, the constellations of Cassiopeia, Perseus, Andromeda, Taurus and Aries are near the meridian, whilst the stars of Orion, Sirius, Procyon, Castor and Pollux are south-east and eastwards. The Geminid meteor shower should be looked for on or about December 11, the radiant point being at R.A. $7^{\mathrm{h}} 12^{\mathrm{m}}$ : Dec. $33^{\circ} \mathrm{N}$. The light variations of Algol may be observed at about December $1^{d} 0^{\mathrm{h}}: 3^{\mathrm{d}} 21^{\mathrm{h}}: 6^{\mathrm{d}} 18^{\mathrm{h}}: 18^{\mathrm{d}} 5^{\mathrm{h}}: 21^{\mathrm{d}} 2^{\mathrm{h}}$ : $23^{\mathrm{d}} 23^{\mathrm{h}}: 26^{\mathrm{d}} 20^{\mathrm{h}}$ and $29^{\mathrm{d}} 17^{\mathrm{h}}$.

\section{Announcements}

The Buchan Prize of the Royal Meteorological Society for 1937 has been awarded to Mr. C. S. Durst, for papers contributed to the Quarterly Journal of the Society during the years 1931-35.

The Mozelle Sassoon High Voltage X-Ray Therapy Department of St. Bartholomew's Hospital, London, will be opened by Mrs. Meyer Sassoon on December 10 at 2.30 p.m., when Lord Rutherford and Lord Horder will speak. A memorial plaque to Dr. R. G. Canti, late clinical pathologist to the Hospital, will be unveiled by Dr. Malcolm Donaldson, director of the Cancer Department.

Messrs. W. Watson \& Sons, Ltrd, of 313 High Holborn, London, W.C., are holding their fourth Annual Exhibition of Microscopes in the Central Hall, Westminster, on December 7-11. In connexion with the Exhibition, several cinematograph films will be shown, and the following lectures will be given: "Science and Vinegar Brewing" (Mr. Sarson); "The Romance of Shell Life" (Mr.'F. Martin Duncan); "Old Instrument-makers" (Mr. R. S. Whipple).

Dr. Frick, the German Home Office Minister, has ordered that specimens of blood should be examined for the presence of alcohol according to Widmark's method in the case of persons apparently under the influence of drink when involved in motor accidents.
According to the Soviet Union Year Book Press Service, the large Soviet Medical Encyclopædia has now been completed. It consists of 35 volumes, containing 6,396 articles and 80,000 terms used in medicine and allied sciences ; 20 academicians, 692 professors and 1,006 other scientific workers have taken part in the production of the Encyclopædia under the editorship of Prof. N. A. Semashko.

THE Leningrad branch of the All-Union Institute of Experimental Medicine is collecting documents relating to the life and work of the late Prof. I. P. Pavlov. The documents are to be added to the collection already in existence at the Pavlov Museum founded by the Leningrad branch. A commission is approaching men of science and scientific institutions abroad for gifts of any material they may have in their possession relating to Pavlov.

WE are informed that the price of Osborn's "Monograph of the Proboscidea" is 20 dollars (Nature, Oct. 31, Supp. p. viii, and Nov. 21, p. 860).

Applications are invited for the following appointments, on or before the dates mentioned :

Lecturer in mechanical engineering in the St. Helens Municipal Technical School-The Director of Education, Education Office, St. Helens (December 8).

Lecturer in mechanical engineering and lecturer in electrical engineering in the Norwich Technical College -The Principal (December 9).

Lecturer in mechanical engineering in the West Hartlepool Technical College-The Secretary for Education, Education Offices, West Hartlepool (December 9).

Temporary assistant engineers, engineering assistants and junior engineering assistants to the Ministry of Transport-The Establishment Officer, Ministry of Transport, Whitehall Gardens, S.W.1 (December 11).

Junior research chemist for work on fuel problems at the Bone Research and Development Association, Ltd.-Prof. W. A. Bone, Imperial College of Science, S.W.7 (December 11).

Research physicist to the Printing and Allied Trades Research Association-The Director of Research, 10 Robin Hood Court, Shoe Lane, London, E.C.4 (December 21).

Chief mining engineer to the Safety in Mines Research Board--The Establishment Officer, Mines Department, Dean Stanley Street, S.W.I (December 31).

Imperial economic botanist at the Imperial Agricultural Research Institute, New Delhi--The High Commissioner for India, General Department, India House, Aldwych, W.C.2 (January 2).

Professor of animal pathology in the University of Cambridge-The Vice-Chancellor (January 12).

Research physicist to the British Cotton Industry Research Association-The Director of Research, Shirley Institute, Didsbury, Manchester.

Principal of the Kadoorie Agricultural School, Mount Tabor, Palestine--The Chief Secretary to the Government of Palestine, Jerusalem. 